\title{
Hartz and Minds: Happiness Effects of Reforming an Employment Agency
}

\author{
Max Deter ${ }^{1}$ (D) \\ Published online: 30 July 2020 \\ (C) The Author(s) 2020
}

\begin{abstract}
Since the labor market reforms around 2005, known as the Hartz reforms, Germany has experienced declining unemployment rates. However, little is known about the reforms' effect on individual life satisfaction of unemployed workers. This study applies differencein-difference estimations and finds a decrease in life satisfaction after the reforms that is more pronounced for male unemployed in west Germany. The effect is driven by income and income satisfaction, but not by the unemployment rate. Also unemployed persons who exogenously lost their jobs are affected by the reforms. In line with the structure of the reforms, the effect is stronger on long-term and involuntarily unemployed persons.
\end{abstract}

Keywords Unemployment $\cdot$ Hartz reforms $\cdot$ Happiness $\cdot$ SOEP

JEL Classification E24 $\cdot$ I31 $\cdot$ J64

\section{Introduction}

Between January 2003 and January 2005, the German government under Gerhard Schröder, a coalition of Social Democrats and the Green Party, implemented a number of labor market reforms, known as the Hartz reforms. Following a decade of rising unemployment rates after reunification, Germany was pressured to bring unemployment down. The reforms increased labor market flexibility (Hartz I-III), and reduced the level and duration of longterm unemployment entitlements (Hartz IV). Additionally, long-term unemployment income was made conditional on job search behavior, with increased possibilities of income sanctions.

Germany experienced in the following years a steadily declining unemployment rate. This development was favored by the Hartz reforms through increased job search and concessions of unemployed workers regarding employment conditions and wages, lower wages for displaced workers after they return to work, improved matching efficiency, and decreased duration in unemployment (Hochmuth et al. 2019; Woodcock 2018; Hertweck

Max Deter

deter@wiwi.uni-wuppertal.de

1 Department of Economics, Bergische Universität Wuppertal, Gaußstraße 20, 42119 Wuppertal, Germany 
and Sigrist 2012; Krause and Uhlig 2012). Nevertheless, Hartz IV remains one of the most controversial topics in the national debate (Die Zeit 2018). The reform is criticized mainly for the (arguably) low income for unemployed workers with a large employment history, strong sanction possibilities, and unfavorable conditions to earn additional income in unemployment (Wirtschaftsdienst 2019). Reform proposals regarding Hartz IV exists from almost all German parliamentary parties, among those that introduced the law (Süddeutsche Zeitung 2019). Internationally, the Hartz reforms are seen as a role model to liberalize the labor market in order to reduce unemployment rates (The Economist 2018).

Despite the scope of the Hartz reforms and their relative importance in the scientific world, relatively little is known about the reforms' effect on life satisfaction of unemployed workers (the terms life satisfaction and happiness are used here synonymously; Happiness is defined as the subjective satisfaction with one's life). This is surprising because life satisfaction influences individual actions substantially and has been broadly analyzed in the economic and psychological research (Oswald 1997; Alesina et al. 2004; Dolan et al. 2008; Diener et al. 2006). Therefore, it is necessary to answer the question whether the reforms made unemployed individuals unhappier. Low happiness levels are strongly associated with poor (mental) health (Headey et al. 1993; Veenhoven 2008). Moreover, while lower individual happiness causes the unemployed to look more intensively for a new job, unhappier unemployed are not more likely to find one (Gielen and Van Ours 2014). Instead, happiness and job finding seem to have an inverted u-shaped relationship, with very happy and very unhappy unemployed persons being the least likely to find a job (Grant and Schwartz 2011).

The current paper adds to the literature on the Hartz reforms the component of happiness. In the analysis, I use data from the German Socio-Economic Panel (SOEP) and find a decrease in life satisfaction after the reforms that is more pronounced for male unemployed in west Germany. Changes in (satisfaction with) household income can partly explain this effect. Also unemployed persons who exogenously lost their jobs are affected by the reforms. In line with the structure of the reforms, the effect is stronger on long-term and involuntarily unemployed workers.

The paper is set up as follows. Section 2 discusses the Hartz reforms and their expected effect on life satisfaction. Section 3 analyzes the data and presents the methodology. Section 4 shows the results and robustness checks. Finally, Sect. 5 concludes.

\section{Happiness and the Hartz Reforms}

\subsection{What Does Happiness Measure?}

There exists a large body of literature on how life events have an impact on happiness, such as a divorce (negative), an exogenous increase in income, for example, by winning the lottery (positive), or unemployment (negative) (Diener et al. 2006; Gardner and Oswald 2007; Clark 2003). The literature on the effect of an external event or political change on happiness is relatively scarce. An example is Berger (2010), who finds with SOEP data that the nuclear catastrophe in Chernobyl in 1986 had a negative effect on environmental concerns in Germany, but only a minimal negative effect on life satisfaction, indicating a relative stability of life satisfaction. Gruber and Mullainathan (2005) use policy variation in U.S. states to show that higher cigarette taxes have a positive happiness effect on individuals that are predicted to be smokers, stating that happiness might be a more suitable proxy for 
utility than income. Using a difference-in-difference approach (DiD) with SOEP data, Collischon et al. (2018) find a positive happiness effect of the abolition of compulsory military service on young males' happiness in Germany, compared to females the same age.

There is not much known about the happiness effect of the Hartz reforms. This is surprising because life satisfaction influences individual actions substantially and has been broadly analyzed in economic, psychological, and sociological research. Self-reported happiness recognizes the fact that "everybody has their own ideas about happiness and a good life" and "people are reckoned to be the best judges of the overall quality of their life, and it is a straightforward strategy to ask them about their well-being" (Frey and Stutzer 2002, p. 405). The authors explain that behind a person's happiness score lies a cognitive assessment of their circumstances compared to other individuals, future expectations, and past experiences. Although happiness statements can be biased, for example by daily moods, they contain a significant true signal about a person's overall satisfaction with life (Schwarz and Strack 1999).

Self-reported happiness is highly correlated with a person's happiness indicated by friends and relatives, the number of smiles per day, and even physiological measures of well-being, such as heart rate and blood pressure (for an overview, see Kahneman 2006). Thus, life satisfaction is also associated with better health (Veenhoven 2008). Therefore, it is desirable to learn more about the happiness effect of such drastic reforms as the Hartz reforms in Germany and I address this topic in my empirical analysis. The changes in the institutional setting of the unemployment scheme in Germany between 2003 and 2005 offer an opportunity for this analysis, with the abolition of the old unemployment scheme resembling the conditions of a natural experiment.

\subsection{Institutional Background}

The focus of the Hartz reforms (2003-2005) was to reduce unemployment by strengthening the supply side of labor. In reducing the level and duration of unemployment entitlements, the government aimed to increase incentives for unemployed individuals to search for and accept jobs. In the first steps (Hartz I-III), the Federal Employment Agency (Bundesagentur für Arbeit) was reformed by enhancing tools for training and job search. Additionally, temporary work and low-income jobs (Mini Jobs) were deregulated (for an overview, see Eichhorst and Marx 2011). The final step, Hartz IV, was the key of the reforms. It substantially changed conditions for the unemployed and remains one of the most controversial political topics in Germany.

The reforms followed a discussion on whether the unemployed put enough effort into gaining employment and whether they are willing to make concessions regarding wages and work conditions. Although unemployed workers receiving social assistance accepted almost every job, persons receiving unemployment assistance could refuse offers of employment if the net income was less than their benefits. The skeptical view on unemployed persons was expressed by then-Chancellor Schröder who stated that "there should be no right to be lazy" (Manager Magazin 2001). In fall of 2004, 21\% of unemployed persons had already been without employment longer than two years, and the rate was increasing (Kettner and Rebien 2007). Politicians were concerned that increasing long-term unemployment was accompanied by a depreciation of knowledge and skill, self-esteem, and, in general, decreasing chances of reemployment. Thus, the incentives to search for employment were enhanced in the reforms. 
Before Hartz IV, the German unemployment system provided long-term unemployed persons, who had a sufficient work history, with relatively generous income support compared to other OECD (Organisation for Economic Co-operation and Development) countries. The framework for unemployment entitlements consisted of three tiers, unemployment insurance (Arbeitslosengeld), unemployment assistance (Arbeitslosenhilfe), and supplementary social assistance (Sozialhilfe). Unemployment insurance was, and still is, paid half by employees and half by employers (tax on labor). Benefits were typically $60-70 \%$ of previous net earnings and were paid up to 12 months, but could be paid up to 36 months for unemployed persons older than 45 years, depending on their work history. Unemployment assistance, a special feature in Germany, but removed in the reforms, were slightly lower state payments (about $55 \%$ of previous net earnings), but with basically no limit on duration. The unemployed who were not eligible for unemployment insurance or unemployment assistance, because they were non-employable or had an insufficient employment history, received means tested and indefinite social assistance, a less generous tax-paid lump sum (Woodcock 2018; Krause and Uhlig 2012).

The new Hartz IV law left unemployment insurance (now Arbeitslosengeld I, or ALG I) largely unchanged. The maximum duration of 12 months remained after the reforms for individuals under 45 years, but was reduced to 18 months for workers over 58 years (15 months for people over 50, 18 months for those over 55), compared to 36 months before (a few years later, the duration was increased again to 24 months for workers over $58)$.

Unemployment assistance and social assistance were merged into "Unemployment Income II" (Arbeitslosengeld II, or ALG II), a means-tested payment at the household level for the basic supply of those able to work and their family members, and much closer to the old social assistance. Additionally to overall fewer payments (compared to unemployment assistance), the introduction of ALG II was accompanied by an increased pressure to accept jobs and to cooperate with local job centers that supervised unemployed workers more closely. Sanctions could afterwards mean a benefit cut of up to $100 \%$ (except housing and heating), when the person repeatedly refuses a job offer or job measure. Persons under 25 years may be subject to a complete cut in benefits after only the first breach of duty (Abraham et al. 2018).

\subsection{The Hartz Reforms and Happiness}

As described above, the direct reform effect on income of the unemployed was mostly negative, although not for all. Older recipients of unemployment insurance lost their claim sooner but all recipients of unemployment insurance slide after the initial period directly into the much lower minimum income support (ALG II). Former recipients of unemployment assistance received ALG II after the reforms and thereby experienced an average income drop of 25\% (Die Zeit 2004). Housing benefits in ALG II were after the reforms more generous, from which unemployed in the west, where housing costs are higher, benefited. The stronger means test after the reforms takes into account the labor income of the partner, and in east Germany, female labor force participation is still higher than in the West, leading to an additional negative effect for unemployed individuals in east Germany. However, (Goebel and Richter 2007) showed that, although more unemployed persons in east Germany lost from the reforms the average income drop is stronger in West Germany. This is due to a previously higher income in unemployment 
insurance and unemployment assistance. Additionally, financial wealth is higher in west Germany, and is accounted for in the new system (for an overview of income effects, see Goebel and Richter 2007).

Income has a positive effect on happiness, but with diminishing returns to income (for an overview, see Clark et al. 2008). Thus, low-income individuals, such as unemployed workers, might lose more from the same income drop compared to richer individuals. Relative (or comparison) income plays a substantial role as well (for an overview, see Ferrer-i-Carbonell 2005), that is, the income relative to either a reference group (friends, colleges, neighborhood) or past income. Unemployed persons with a large drop in income are expected to be adversely affected from the reforms, also because of their relatively lower income compared to the past and compared to their former reference group. Moreover an income drop at this level (ALG II was 345 Euro in 2005 for a single person excluding housing and heating, Statista 2020) is associated with a situation in which an individual is less able to meet his or her financial obligations, societal expectations, and social standards. Consequently, an unemployed person may feel humiliated, degraded, or ashamed, which lowers life satisfaction (Layard 2011).

(Older) long-term unemployed workers with a rich employment history might not only be affected by a lower income under ALG II, but also by a lower social status, since they have the same status and duties after the reforms as those who never worked. This would negatively influence happiness (Eggs 2013). Individuals in ALG II have to deal with increased stigmatization, compared to those receiving unemployment insurance (Zick et al. 2019). Women usually suffer less from unemployment than men, due to a weaker work norm and the need to care for children (Clark 2003). Since the Hartz reforms had potentially an adverse effect on the social norm, men might have been more strongly affected.

A higher pressure to search for work and accept jobs occurred after the reforms (Kettner and Rebien 2007). This is expected to have a negative effect on happiness, since involuntary unemployment, measured by job search and job acceptance behavior, is associated with a lower life satisfaction compared to those voluntarily in unemployment, since the involuntarily unemployed are dissatisfied with their current situation (Chadi 2010). Income sanctions increase the willingness to work and the integration into the labor market, but can increase stress levels (Thomsen et al. 2009). The threat of sanctions and the duty to accept jobs might lower the feeling of having control over one's life, an important determinant of life satisfaction (Warr 1987).

However, a large number of unemployed workers experienced no substantial income changes. Positive effects on life satisfaction might result for unemployed persons who experienced increases in income through the means test at the household level and higher housing support. Moreover, generally better employment opportunities through the labor market liberalization and lower unemployment rates might increase life satisfaction, for example through a lower duration in unemployment (Lucas et al. 2004). However, Clark (2003) finds that happiness is lower when there is less unemployment locally, increasing the work norm, and thus reducing confidence for unemployed workers.

Given the state of literature and theoretical considerations, I derive the following hypotheses:

H1: The Hartz reforms lowered life satisfaction of unemployed workers.

H2: This effect is driven by variations in income and satisfaction with income, but noneconomic effects play a role as well. 
H3: Long-term unemployed persons with a relatively high employment experience suffered more from the reforms than the average unemployed worker.

\section{Data and Methodology}

\subsection{Sample and Measures}

In the empirical analysis, I use unbalanced panel data from the German Socio-Economic Panel (GSOEP), an annual panel survey, as representative of the resident German population (Goebel et al. 2019). In 2006, there were nearly 11,000 households, and more than 20,000 persons surveyed. The database contains extensive information on the individual and the household levels, such as demographic factors, labor market positions, and subjective satisfaction measures. Following Chabé-Ferret (2015) I keep the difference-indifference estimation (DiD) symmetric around the treatment date by restricting the sample period to 2001-2006, i.e., two years before and two years after the treatment years of 2003-2004, when the reforms were implemented. Only individuals in the working age 18-65 years are included that are either unemployed (treatment group) or full or part-time employed (reference group). This leads to a sample of 21,660 individuals with 81,721 observations (see Table 1).

Life satisfaction was based on the question "Please answer on a scale from 0 to 10 , where 0 means completely dissatisfied and 10 means completely satisfied. How satisfied

Table 1 Descriptive statistics Source: SOEP 2001-2006, unbalanced panel, own calculations

\begin{tabular}{lll}
\hline & $(1)$ & $(2)$ \\
& Employees & UE \\
\hline Life satisfaction (0-10) & 7.11 & 5.63 \\
Age & 41.52 & 42.86 \\
Education & 1.83 & 1.34 \\
No formal education & 0.10 & 0.19 \\
Secondary school: 9 years & 0.26 & 0.38 \\
Secondary school: 10 years & 0.35 & 0.34 \\
General qual. for university: 12/13 years & 0.29 & 0.10 \\
Employment experience in years & 18.12 & 16.94 \\
Share of people in east & 0.21 & 0.41 \\
Having a partner & 0.75 & 0.66 \\
Children living in HH & 0.41 & 0.38 \\
Homeowner & 0.53 & 0.32 \\
Satisfaction with HH Income (0-10) & 6.48 & 4.12 \\
Financial worries (1-3) & 1.96 & 2.53 \\
Regional unemployment rate (federal state level) & 11.83 & 14.29 \\
Active job search last 4 weeks & & 0.61 \\
Would take a job & & 0.76 \\
Unemployment duration (in months) & & 8.33 \\
Observations & 74,644 & 7077 \\
\hline
\end{tabular}


are you with your life, all things considered." Figure 1 shows the distribution of answers to the question on life satisfaction for employed and unemployed persons.

Control variables are age and education. Education dummies are created for No formal education ("Education 1"), 9 years of secondary school (Hauptschule, "Education 2"), 10 years of secondary school (Realschule, "Education 3"), and general qualification for university (Abitur, "Education 4"). The highest educational level is the reference point in the regression and therefore not shown. Any other control variable in a DiD framework, such as income or labor market experience, can be considered bad controls (Angrist and Pischke 2008) because they could themselves be outcomes of the treatment (the Hartz reforms) correlated at the same time with happiness.

For additional analyses, potentially confounding factors are analyzed. Logarithmized equivalent net household income is used to measure income as a driver of the results. In this concept of household income the first adult has a weight of one, additional adults a weight of 0.5 and a child under 14 a weight of 0.3 . Thus, for 2 adults and one child under 14 for example, the household income is divided by $(1+0.5+0.3)$. More information on the "OECD modified equivalence scale" can be found on the OECD website http://www. oecd.org/els/ soc/OECD-Note-EquivalenceScales.pdf. Furthermore, income satisfaction (measured the same way as life satisfaction) and the regional unemployment rate (at the federal state level, Federal Statistical Office of Germany 2020) are used for the confounding analysis.

\subsection{Methodology}

The Hartz Reforms, in this case the treatment, affected all regions and applied to all workers. There is therefore no control group that was unaffected by the reforms. However, because the reforms were mostly targeted at job search and unemployment benefits, it is expected that they have the greatest impact on unemployed persons, the treatment group, and to have little or no effect on employees, the reference group. This is similar to Woodcock (2018) who studied the post-unemployment wages after the Hartz reforms

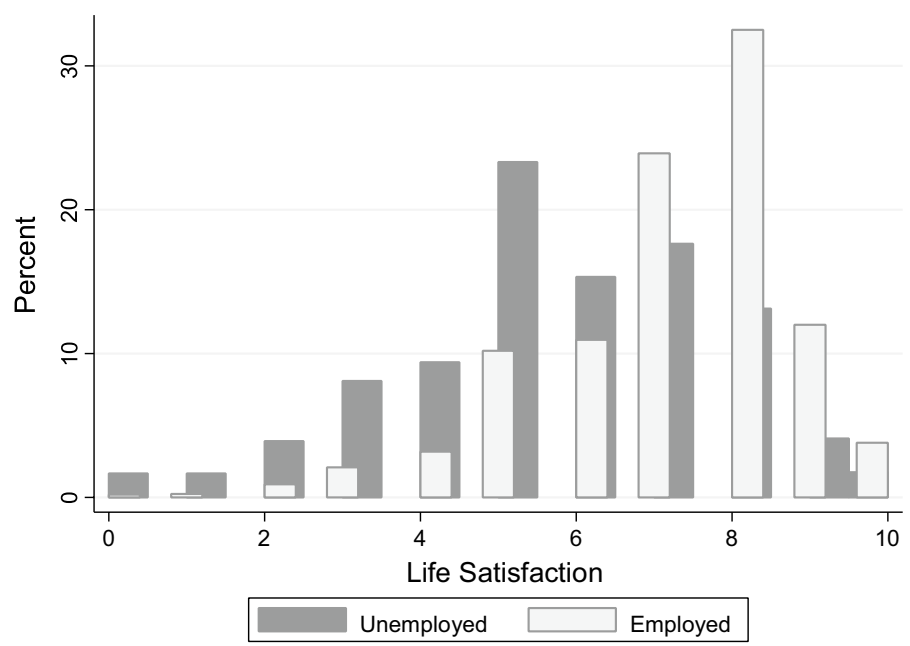

Fig. 1 Distribution of life satisfaction. Source: SOEP 2001-2006, unbalanced panel, own calculations. Note: $0=$ not satisfied at all; $10=$ totally satisfied 
in a DiD framework with recently unemployed persons as the treatment group and continuously employed persons as the reference group. Literature on the Hartz reforms on the matching efficiency, unemployment (duration), and wages use different approaches and have therefore no reference group (Hertweck and Sigrist 2012; Krause and Uhlig 2012; Arent and Nagl 2011). In an additional test, the robustness of the results is tested with a different control group, namely non-employed persons, thus, individuals who are out of the labor market (Sect. 4.3).

The basic strategy is to estimate the effect of the Hartz reforms in a DiD framework that compares the pre- and post-reform level of self-reported life satisfaction of unemployed compared to employed individuals. The parallel trend assumption is discussed in the robustness Sect. 4.3. The $\mathrm{DiD}$ approach allows to explore the identifying variation within the treatment and reference group respectively. The following equation is tested:

$$
\mathrm{LS}_{\mathrm{it}}=\alpha+\gamma \mathrm{UE}_{\mathrm{it}}+\lambda_{1} \text { During }_{\mathrm{t}}+\lambda_{2} \operatorname{Hartz}_{\mathrm{t}}+\beta_{1}\left(\mathrm{UE}_{\mathrm{i}} * \text { During }_{\mathrm{t}}\right)+\beta_{2}\left(\mathrm{UE}_{\mathrm{i}} * \operatorname{Hartz}_{\mathrm{t}}\right)+v_{i}+\varepsilon_{\mathrm{it}}
$$

where $L S_{i t}$ is life satisfaction for an individual $\mathrm{i}$ in year $\mathrm{t} ; U E_{i t}$ is a dummy that equals one if a person is unemployed, and $\mathrm{Hartz}_{t}$ equals one if an individual is surveyed after the reform; $U_{i}^{*} \mathrm{Hartz}_{t}$ is one if an individual is unemployed after the reforms. $\alpha$ is the average level of life satisfaction of the employed before the reforms; $\gamma$ is the difference in the level of life satisfaction between the unemployed and the employed before the reform; $\lambda_{2}$ is the difference of life satisfaction after versus before the reforms, and $\beta_{2}$ is the difference of being unemployed after the reforms compared to before the reforms, minus the difference of being in the control group after versus before the reforms (Angrist and Pischke 2008). $\beta_{2}$ is here the treatment effect and the coefficient of interest. If the coefficient is not zero and significant, there might be evidence that the policy created significantly different happiness outcomes for both groups. $v_{i}$ is an individual fixed effect and $\varepsilon_{i t}$ is the statistical error term.

The control for during the reform, $\lambda_{1}$ During $_{t}$, which equals one if a person is surveyed in the years 2003 and 2004, and a control for being unemployed during the reform, $\beta_{1}\left(U E_{i}^{*}\right.$ During $\left._{t}\right)$, are included in the regressions. Having these controls in the regression reflects the fact that the Hartz reforms were introduced at stages between 2003 and 2005.

Life satisfaction of the unemployed is likely to have been partially exposed to the reforms (Woodcock 2018). Moreover, since media coverage was very strong during the implementation of the reform, anticipation effects on life satisfaction are likely to have happened. It should be noted here that the reforms ended on January 1, 2005, therefore, all individuals surveyed in 2005 are already fully exposed to the reforms.

Time and regional fixed effects are applied to control for year-to-year and regional variation, such as variances in GDP or other policy changes that cannot be explained by the independent variable. Personal fixed effects are included that capture time-invariant personal factors, such as personality or optimism, thus, unobserved individual heterogeneity. Applying fixed effects is suggested for happiness studies (Ferrer-i-Carbonell and Frijters 2004). Next to personal fixed effects, also age and education are included as control variables, even if education does not vary substantially for one individual. The life satisfaction scale was interpreted cardinally in the analysis and least squares estimation techniques were applied, as recommended by Ferrer-i-Carbonell and Frijters (2004), who showed that assuming cardinality or ordinality of life satisfaction answers is relatively unimportant to the results, but cardinality can be interpreted more easily and intuitively. Standard errors are clustered at the individual level to account for the panel structure of the data. 


\section{Results}

\subsection{Main Effects}

Table 2 shows the main results of Eq. (1). In column 1, an ordinary least squares regression without personal fixed effects is applied. The coefficient of interest $U E^{*} H a r t z$ is significant at the $1 \%$ level. Applying personal fixed effects (column 2), the effect of the Hartz reforms on life satisfaction of the unemployed becomes larger, while the UE*DuringHartz effect becomes smaller. The results suggests that the Hartz reforms had a significantly negative effect on unemployed individuals with a magnitude of -0.21 points on the $0-10$ happiness scale, when all controls and the reform effect on the reference group are taken into account.

In column 3 only individuals that live in Western federal states are analyzed, thus, former GDR federal states are excluded. The effect becomes stronger for unemployed persons in former west Germany, compared to employees in former west Germany. This might be due to a stronger average loss in income in west Germany, induced by the Hartz

Table 2 Main effects

\begin{tabular}{|c|c|c|c|c|}
\hline & (1) & (2) & (3) & (4) \\
\hline & LS & LS & LS former west & LS male \\
\hline UE & $-1.14 * * *$ & $-0.64 * * *$ & $-0.62 * * *$ & $-0.74 * * *$ \\
\hline & $(0.04)$ & $(0.05)$ & $(0.06)$ & $(0.06)$ \\
\hline Hartz & $-0.19 * * *$ & 0.07 & 0.11 & 0.03 \\
\hline & $(0.02)$ & $(0.07)$ & $(0.08)$ & $(0.09)$ \\
\hline UE*Hartz & $-0.19 * * *$ & $-0.21 * * *$ & $-0.28 * * *$ & $-0.25 * * *$ \\
\hline & $(\mathbf{0 . 0 5})$ & $(0.06)$ & $(0.08)$ & $(0.08)$ \\
\hline DuringHartz & $-0.29 * * *$ & $-0.15 * * *$ & $-0.12 * *$ & $-0.17 * * *$ \\
\hline & $(0.02)$ & $(0.05)$ & $(0.06)$ & $(0.06)$ \\
\hline UE*DuringHartz & $-0.17 * * *$ & $-0.11^{* *}$ & $-0.18 * * *$ & $-0.12 *$ \\
\hline & $(0.05)$ & $(0.05)$ & $(0.07)$ & $(0.07)$ \\
\hline Age & $-0.00 * * *$ & $-0.10 * * *$ & $-0.10 * * *$ & $-0.08 * * *$ \\
\hline & $(0.00)$ & $(0.01)$ & $(0.02)$ & $(0.02)$ \\
\hline Education 1 & $-0.45^{* * *}$ & -0.13 & -0.01 & 0.19 \\
\hline & $(0.02)$ & $(0.12)$ & $(0.13)$ & $(0.17)$ \\
\hline Education 2 & $-0.43^{* * *}$ & -0.09 & -0.11 & 0.11 \\
\hline & $(0.02)$ & $(0.18)$ & $(0.20)$ & $(0.19)$ \\
\hline Education 3 & $-0.29 * * *$ & -0.01 & 0.06 & 0.07 \\
\hline & $(0.02)$ & $(0.11)$ & $(0.12)$ & $(0.13)$ \\
\hline Constant & $7.89 * * *$ & $11.34 * * *$ & $11.58 * * *$ & $10.77 * * *$ \\
\hline & $(0.04)$ & $(0.62)$ & $(0.69)$ & $(0.84)$ \\
\hline Year and regional FE & Yes & Yes & Yes & Yes \\
\hline Personal FE & No & Yes & Yes & Yes \\
\hline No. of Obs. & 81,721 & 81,721 & 63,392 & 43,990 \\
\hline (Within-) $R^{2}$ & 0.089 & 0.037 & 0.035 & 0.046 \\
\hline
\end{tabular}

Standard errors in parentheses; $* * * \mathrm{p}<0.01, * * \mathrm{p}<0.05$, *p $<0.1$; SOEP 2001-2006, unbalanced panel, own calculations; $R^{2}$ : first column $R^{2}$, column 2-4 within- $R^{2}$

Bold indicates the effect of the treatment on the treatment group, thus, the main effect of the regression 
reforms (Goebel and Richter 2007). When applying the regression for a subsample of male respondents, the effect is stronger than for the whole sample. This can possibly be explained by a larger drop owing to the social norm. The social norm plays a larger role for unemployed men, as they are still considered as the classical bread winner and are found to be unhappier in unemployment than women (Clark et al. 2008).

\subsection{Drivers of the Results and Heterogeneous Effects}

Although results indicate that the overall reform effect on life satisfaction of unemployed workers is negative, several questions remain. Which confounding factors drive the results? Is a different composition of unemployed workers responsible for the drop in happiness? And which subgroups are mostly affected by the reforms? Table 3 aims at responding to these questions. Column 1 is the reference regression, the main effects of Table 2 (column 2).

\subsubsection{Confounding Factors}

From the theoretical section income is expected to drive part of the results. When household income enters the regression (column 2), the magnitude of the coefficient of interest is reduced from -0.21 to -0.17 , indicating that the negative happiness effect, induced by the reforms, can partly be explained by variations in income. However, the measure of income is imperfect, as it functions merely as a proxy on what an individual can spend the available income on. Even if an unemployed person experiences a drop in unemployment income induced by the reforms, the household income could be relatively stable as it takes into account, for example, the income of the partner and the number of children in the household (see Sect. 3.1). However, the drop in unemployment income (instead of household income, as shown here) could mean that the unemployed person is more dependent on the income of the partner, which could additionally lower individual life satisfaction due to a potentially lower self-esteem. Moreover, a lower unemployment income reflects a diminishing respect of society and the state for unemployed individuals. This cannot be measured with the equivalent household income.

To take into account the psychological dimension of income, satisfaction with household income enters the regression in column 3. The magnitude of the coefficient of interest (UE*Hartz) is substantially reduced and the effect is less significant, indicating that income satisfaction plays an important role in explaining the negative happiness effect of the reforms.

\subsubsection{Endogeneity Problems}

Another potential driver of the reforms could induce endogeneity problems in the regression. If the Hartz reforms reduced the incentives to leave one's job more or less voluntarily to draw welfare benefits, then there would be less voluntarily unemployed persons and a higher share of truly involuntary unemployment after the reforms. Chadi (2010) showed that involuntarily unemployed persons are significantly unhappier than voluntarily unemployed. Unhappy persons would, thus, remain in unemployment, while happier individuals leave unemployment and a lower number of (happier) voluntary unemployed persons would enter unemployment. This modified composition, i.e. that the "old" group of (involuntarily) unemployed persons remain, could show up as a negative effect of the Hartz reforms, although it is not. To analyze this problem, three additional drivers of the 


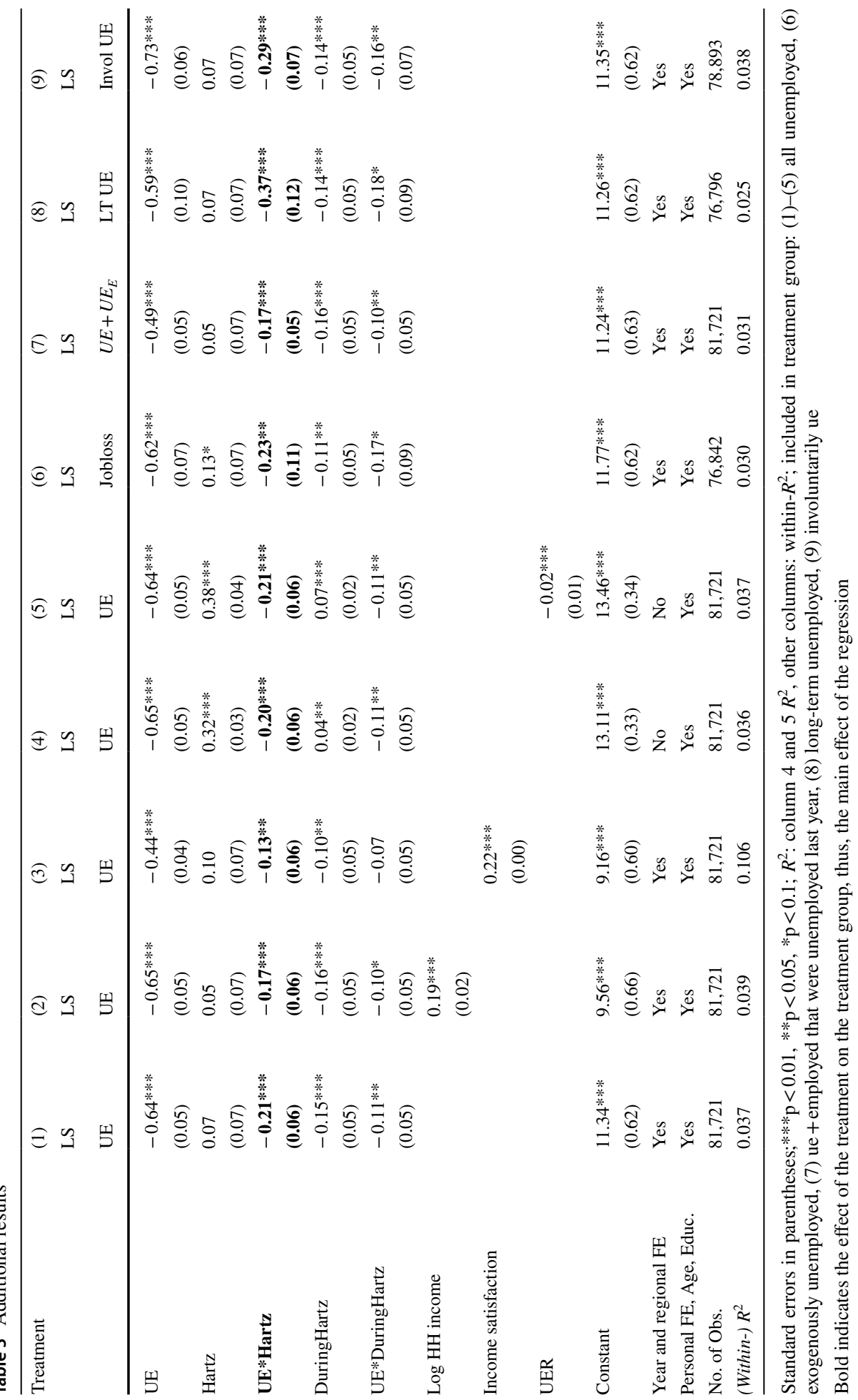


results are tested, namely the effect of the unemployment rate, the share of involuntarily unemployed workers, and the impact on exogenously unemployed workers.

A possible reduction of unemployment, induced by the reforms' incentives to leave unemployment, could potentially reduce happiness of unemployed persons, i.e. happy individuals found more often a job and unhappier individuals remained in unemployment, making overall unemployed individuals unhappier. Following Clark (2003), unemployed individuals are unhappier when there is less unemployment around, because they deviate stronger from the work norm. Column 4 shows the main effect without year and fixed effects in order to compare it with the effect when the regional unemployment rate enters the regression (column 5). Regional unemployment levels do not affect the happiness impact of the reforms. It is important to note that a reduction of the unemployment rate was not present in the observed years (until 2006), but occurred only in the years thereafter. The unemployment rate was with $9.4 \%$ in December 2006 similar to before the reforms (9.2\% in December 2002) (Eurostat 2020).

The endogeneity problem, thus, that the composition of unemployment changed, can furthermore be tested when looking into the present SOEP sample that shows indeed a lower share of individuals quitting their job voluntarily after the reforms than before (2.13\% of all unemployed in 2005-2006, compared to 4.04\% in 2001-2002). A voluntary quit equals one if an unemployed person states to have quit his or her employment relation since last year. Moreover, less individuals were voluntarily unemployed (in the sense that they have not looked for a job within the last 4 weeks and would not take a job if offered) after the reforms than before (19\% compared to $29.41 \%$ ). This points in the direction that higher involuntary, and thus unhappier, unemployment is partly responsible for the results.

To analyze whether the results are only driven by "old" unemployed individuals that were stuck in unemployment, it is tested whether also exogenously unemployed individuals were unhappier after the reforms. For this, individuals are considered in the treatment group who lost their job involuntarily since last year, i.e. due to a plant closure, a dismissal by the employer, or the end of a temporary contract. If this group is also negatively affected by the reforms, it can be stated that the composition of unemployed individuals is not the only driver of the results, and the endogeneity problem plays not a major role here. In theory, individuals that recently lost their job are affected by the reforms by either sliding into the newly created ALG II if they have not worked enough months (with much worse conditions than before the reforms), or by a shorter duration of unemployment income (ALG I) and by the fear of sliding soon into ALG II. The results (column 6) indicate that also exogenous unemployed persons were negatively affected by the reforms, although at a lower significance level. This adds to the story that endogeneity problems do not necessarily drive the happiness results, but rather that the changed conditions in unemployment are responsible for the effect.

\subsubsection{Overall Effect of the Reforms}

One could argue that although the happiness effect of the Hartz reforms on unemployed persons is negative, the overall effect is positive, i.e. more individuals moved from unemployment into employment after the reforms and are thus happier. However, in the SOEP sample, the share of persons who switched from unemployment to employment is relatively stable in the sample period (before the reforms, 2001-2002, 25.49\%; after the reforms, 2005-2006, 27.25\%). To calculate the overall effect of the Hartz reforms, those who found a job are included as treated individuals in the happiness equation (in addition 
to unemployed persons). The reference group is, thus, employed persons who were not unemployed last year. If the effect of the coefficient (UE*Hartz, here: UE plus individuals who found a job) is insignificant, the reforms had no negative overall impact. However, even when including those who found a job, the effect is still negative (column 6), indicating an overall negative effect of the reforms, that is present at least in the short-run (two years after the reforms).

\subsubsection{Subgroups}

From the structure of the Hartz reforms, it is reasonable to assume that not all unemployed workers were affected the same way. Especially long-term unemployed individuals with an ample employment history were affected by the reforms (hypothesis 3), since most of them fell from the relatively comfortable unemployment assistance into ALG II, an existence minimum with strong obligations and total sanction possibilities. Employment experience is full-time or part-time employment in years. An individual is defined as long-term unemployed if the person is longer than 12 months in unemployment (Statista 2019). In column 8 , results show that the effect on this subgroup is more pronounced than the average effect and can be explained by the structure of the reforms that targeted especially long-term unemployed persons. Employment experience of unemployed persons (in years), however, does not play a role in explaining heterogeneous effects (not shown here).

Job search behavior is captured by the question whether the unemployed has "actively searched for a new job within the last four weeks?" and "If someone offered you an appropriate position right now, could you start working within the next two weeks?". If both questions are answered with "Yes", a person is defined as involuntarily unemployed, since the person wants to change his or her current situation. When the treatment group is reduced to involuntary unemployed persons, the effect of the Hartz reforms becomes much stronger in magnitude (column 9). This suggests that especially involuntary unemployed persons suffered from the reforms, i.e. those who want to leave unemployment. This shows that the reforms were successful in designing incentives to look stronger for a job, because involuntarily unemployed persons are more dissatisfied with their situation than before. The negative effect on involuntary unemployed can also be explained by a feeling of injustice for persons who were already eager to find work, but, after the reforms, experienced additional pressure from job centers to search for work.

\subsection{Robustness Tests}

\subsubsection{Alternative Outcomes}

Additional outcomes are considered in a further step that might have been affected by the reforms (Table 4 in "Appendix"). This is carried out as an attempt to analyze whether the Hartz reforms had also an impact on outcomes that are similar to life satisfaction. The table shows that the Hartz reforms reduced income satisfaction of unemployed individuals stronger than life satisfaction (column 1). The result is intuitive, since the reforms especially reduced unemployment income, but it also shows the psychological dimension of the reforms. Next, the reform effect on financial worries is analyzed (measured on a scale of $1-3$, where 1 means "not concerned" and 3 "very concerned"), a concept that rather deals with worries about the future development of own finances. However, no significant effect can be observed on financial worries (column 2). 
Table 4 Alternative outcomes

\begin{tabular}{|c|c|c|c|}
\hline & $\begin{array}{l}\text { (1) } \\
\text { Income Sat }\end{array}$ & $\begin{array}{l}\text { (2) } \\
\text { Fin. worries }\end{array}$ & $\begin{array}{l}\text { (3) } \\
\text { Trust }\end{array}$ \\
\hline UE & $\begin{array}{l}-0.95^{* * *} \\
(0.06)\end{array}$ & $\begin{array}{l}0.25 * * * \\
(0.02)\end{array}$ & $\begin{array}{l}-0.12 * \\
(0.07)\end{array}$ \\
\hline Hartz & $\begin{array}{l}-0.15^{*} \\
(0.08)\end{array}$ & $\begin{array}{l}0.32 * * * \\
(0.03)\end{array}$ & $\begin{array}{l}-0.03 * \\
(0.01)\end{array}$ \\
\hline UE*Hartz & $\begin{array}{l}-0.33 * * * \\
(\mathbf{0 . 0 7})\end{array}$ & $\begin{array}{l}0.01 \\
(0.02)\end{array}$ & $\begin{array}{l}0.12 \\
(0.08)\end{array}$ \\
\hline DuringHartz & $\begin{array}{l}-0.21 * * * \\
(0.06)\end{array}$ & $\begin{array}{l}0.28 * * * \\
(0.02)\end{array}$ & \\
\hline UE*DuringHartz & $\begin{array}{l}-0.18^{* * *} \\
(0.06)\end{array}$ & $\begin{array}{l}-0.02 \\
(0.02)\end{array}$ & \\
\hline Age & $\begin{array}{l}-0.06^{* * *} \\
(0.02)\end{array}$ & $\begin{array}{l}-0.02^{* * * *} \\
(0.01)\end{array}$ & \\
\hline Education 1 & $\begin{array}{l}-0.00 \\
(0.19)\end{array}$ & $\begin{array}{l}0.03 \\
(0.06)\end{array}$ & $\begin{array}{l}-0.35 \\
(0.29)\end{array}$ \\
\hline Education 2 & $\begin{array}{l}-0.18 \\
(0.26)\end{array}$ & $\begin{array}{l}-0.08 \\
(0.08)\end{array}$ & $\begin{array}{l}-0.83 \\
(0.71)\end{array}$ \\
\hline Education 3 & $\begin{array}{l}-0.06 \\
(0.18)\end{array}$ & $\begin{array}{l}0.01 \\
(0.05)\end{array}$ & $\begin{array}{l}-0.20 \\
(0.28)\end{array}$ \\
\hline Constant & $\begin{array}{l}10.06^{* * * *} \\
(0.80)\end{array}$ & $\begin{array}{l}2.58 * * * \\
(0.25)\end{array}$ & $\begin{array}{l}1.22 * * * \\
(0.34)\end{array}$ \\
\hline Year, Reg., Pers. FE & Yes & Yes & Yes \\
\hline No. of Obs. & 81,721 & 81,431 & 25,571 \\
\hline$\left(\right.$ Within-) $R^{2}$ & 0.042 & 0.044 & 0.003 \\
\hline
\end{tabular}

Standard errors in parentheses; $* * * \mathrm{p}<0.01$, **p $<0.05, * \mathrm{p}<0.1$; in model 3 Age drops out because it is collinear with the control variable "Hartz", because the regression is applied only for two years (2003 and 2008)

Bold indicates the effect of the treatment on the treatment group, thus, the main effect of the regression

The reforms are expected to not only have an impact on income, but also on non-economic effects. A stronger stigmatization of "Hartz recipients" was demonstrated in the theory section. Although non-economic effects are already partly measured by life satisfaction, additionally, two measures of trust are used to measure stigmatization, namely the questions "On the whole one can trust people" (1-4 scale; 1: totally agree, 4: totally disagree) and "Nowadays can't trust anyone" (1-4 scale) (Dohmen et al. 2012; Kosse et al. 2020; Deter 2020). The first measure is subtracted from the second measure so that higher values correspond to higher trust (scale of -3 to 3 ). Trust is a reasonable proxy for stigmatization, since a higher stigmatization can lead to lower trust towards other people in society.

Questions about personal trust are asked only in 2003 and 2008, wherefore it is analyzed if unemployed workers in 2008 had lower trust levels than in 2003 (the year in which the reforms started), conditional on the difference of trust in employed individuals. Although results indicate a general lower level of trust for unemployed individuals than for 
employees, the reforms had no negative effect on trust of unemployed persons, at least not three years after the reforms.

\subsubsection{Parallel Trend Assumption}

The main identifying assumption for a DiD approach is the parallel trend assumption, i.e. in the absence of the treatment (the Hartz reforms), life satisfaction of the treated (unemployed persons) would have followed the same trend as for the reference group (employed persons). As this is not observable, the common trend assumption is not formally testable, but Fig. 2 (in "Appendix") shows that the respective change of average satisfaction levels before the reforms (2001-2002) is similar for both the treated and the reference group, supporting evidence of the common trend assumption.

In a further step, I test the main regression for the period 1999-2002, where the years 2001-2002 function as the placebo treatment period (Table 5 in "Appendix"). The placebo test is carried out to analyze whether an underlying trend for unemployed persons but not for employed persons would be present already before the real treatment, the Hartz reforms. Then, the regression would indicate a significant effect on the coefficient of interest $U E^{*}$ Placebo (in accordance with $\beta_{2}$ in Eq. 1). However, the table shows that life satisfaction has not differed between treated and control group before the reforms. This supports the hypothesis that the main effect was indeed induced by the Hartz reforms.

\subsubsection{Alternative Control Group}

To analyze whether the results hold for an alternative reference group, the main result is tested in a regression on unemployed persons (treated group) with non-employed individuals as the reference group. This group consists of individuals in the working age (18-65) who are neither in employment nor in education. Furthermore, they are not unemployed

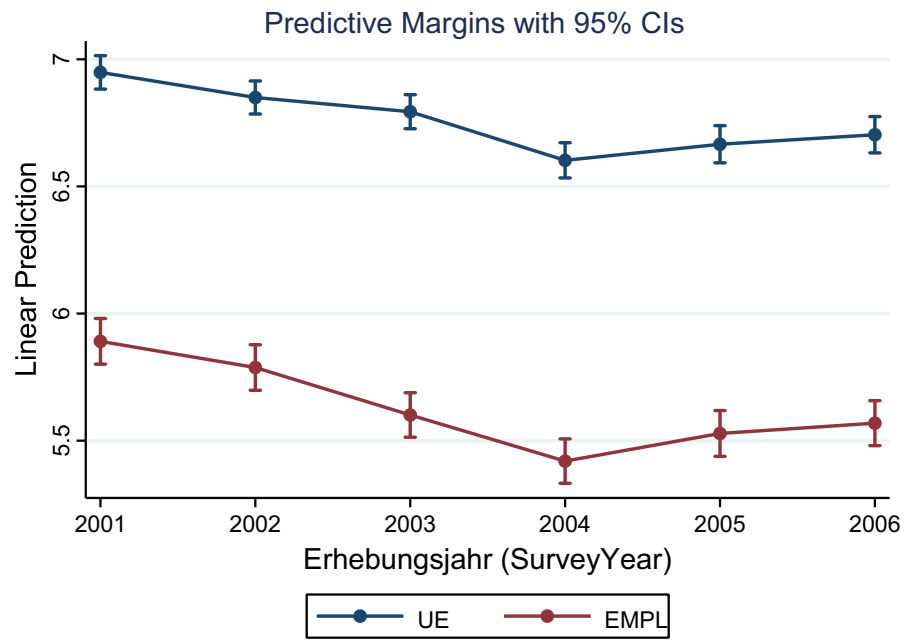

Fig. 2 Trends in life satisfaction before and after the Hartz reforms. Source: SOEP 2001-2006, unbalanced panel, own calculations. Note: Predictive margins with confidence interval of $95 \%$; annual means by group (employed = above, unemployed = below) adjusted for observable characteristics (age, education, regional and year effects); 2003 is the year of the Hartz reforms 
UE $-0.74 * * *$ (0.06)

Placebo $0.30 * * *$ (0.04)

UE*Placebo 0.08 (0.06)

Age $-0.18 * * *$ (0.01)

Education 1 0.08

Education 2

Education 3

$0.17 * *$

Constant $13.60 * * *$

Year, Reg., Pers. FE

Yes

No. of Obs.

0.022

(Within-) $R^{2}$

Standard errors in parentheses; $* * * \mathrm{p}<0.01$, ** $\mathrm{p}<0.05, * \mathrm{p}<0.1$; Pretreatment period: 1999-2000, post-treatment period: 2001-2002

Bold indicates the effect of the treatment on the treatment group, thus, the main effect of the regression

since they are not available for the labor market and currently do not look for a job, and do therefore not receive unemployment income. Non-employed individuals can be, for example, homemakers with a working partner, or individuals who are in between jobs and do not want to fill out forms to receive unemployment income (out of the labor force). Similarly to employees, non-employed persons were not directly affected by the reforms, as the reforms have not directly affected their income, duties, and status. They are therefore suited as a potential reference group. The results (Table 6 in "Appendix") confirm the robustness of the main results, with a similar magnitude of the coefficient $U E^{*} H a r t z$ and with a smaller significance level. Thus, the main results hold also for a different control group.

\section{Conclusions}

The Hartz reforms were introduced to address high unemployment rates in Germany. A key aspect of the reforms was the Hartz IV law that changed conditions foremost for longterm unemployed persons, to increase their ability to find jobs. Lower unemployment entitlements, a stronger duty to apply for jobs, and strong sanction possibilities potentially increased concessions unemployed individuals had to make regarding employment quality and wages. It also potentially lowered their life satisfaction. Despite ongoing discussions 
Table 6 Alternative control group (non-employed persons)
UE $-0.15^{* *}$ (0.06)

Hartz 0.04 $(0.16)$

UE*Hartz $-0.17 * *$ (0.07)

DuringHartz $-0.15$

UE*DuringHartz $-0.07$ (0.06)

Age $-0.09 * *$ (0.04)

Education 1 $-0.26$

Education 2 $-0.06$

Education 3

Constant $11.76^{* * * *}$ (1.77)

Yes

0.018

(Within-) $R^{2}$

Standard errors in parentheses; $* * * \mathrm{p}<0.01, * * \mathrm{p}<0.05,{ }^{*} \mathrm{p}<0.1$

Bold indicates the effect of the treatment on the treatment group, thus, the main effect of the regression

of the Hartz reforms in the national and international public and scientific world, little is known about the happiness effect of the reforms.

Using data from the German Socio-Economic Panel (GSOEP), this empirical study showed that unemployed persons became unhappier after the reforms. The effect can partly be explained by income and income satisfaction. Also unemployed persons who exogenously lost their jobs are affected by the reforms. In line with the structure of the modified conditions in the Hartz framework, the reforms had a stronger impact on long-term and involuntarily unemployed persons. The current paper adds to the literature on the Hartz reforms the component of happiness. This is important because a drop in happiness leads to stronger job search, but is not associated with a better job finding. While many individuals gained from the Hartz reforms through better employment opportunities in the long run, others have lost from it and might be at risk of fully withdrawing from the labor market. The results showed that individuals are affected differently from the reforms. This should be taken into account in reform proposals regarding Hartz IV. 
Acknowledgements Open Access funding provided by Projekt DEAL.

\section{Compliance with Ethical Standards}

Conflict of interest The authors declare that they have no conflict of interest.

Ethical Approval This article does not contain any studies with human participants or animals performed by any of the authors.

Open Access This article is licensed under a Creative Commons Attribution 4.0 International License, which permits use, sharing, adaptation, distribution and reproduction in any medium or format, as long as you give appropriate credit to the original author(s) and the source, provide a link to the Creative Commons licence, and indicate if changes were made. The images or other third party material in this article are included in the article's Creative Commons licence, unless indicated otherwise in a credit line to the material. If material is not included in the article's Creative Commons licence and your intended use is not permitted by statutory regulation or exceeds the permitted use, you will need to obtain permission directly from the copyright holder. To view a copy of this licence, visit http://creativecommons.org/licenses/by/4.0/.

\section{Appendix}

See Fig. 2, Tables 4, 5, and 6.

\section{References}

Abraham, M., Rottmann, M., \& Stephan, G. (2018). Sanktionen in der Grundsicherung: Was als gerecht empfunden wird. IAB-Kurzbericht, 19/2018.

Alesina, A., Di Tella, R., \& MacCulloch, R. (2004). Inequality and happiness: Are Europeans and Americans different? Journal of Public Economics, 88(9-10), 2009-2042.

Angrist, J. D., \& Pischke, J.-S. (2008). Mostly harmless econometrics: An empiricists' companion. Princeton: Princeton University Press.

Arent, S., \& Nagl, W. (2011). Unemployment benefit and wages: The impact of the labor market reform in Germany on (reservation) wages. Ifo Working Paper, 101.

Berger, E. M. (2010). The Chernobyl disaster, concern about the environment, and life satisfaction. Kyklos, $63(1), 1-8$.

Chabé-Ferret, S. (2015). Analysis of the bias of matching and difference-in-difference under alternative earnings and selection processes. Journal of Econometrics, 185(1), 110-123.

Chadi, A. (2010). How to distinguish voluntary from involuntary unemployment: On the relationship between the willingness to work and unemployment-induced unhappiness. Kyklos, 63(3), 317-329.

Clark, A. E. (2003). Unemployment as a social norm: Psychological evidence from panel data. Journal of Labor Economics, 21(2), 323-351.

Clark, A. E., Frijters, P., \& Shields, M. A. (2008). Relative income, happiness, and utility: An explanation for the Easterlin paradox and other puzzles. Journal of Economic Literature, 46(1), 95-144.

Collischon, M., Eberl, A., \& Jahn, K. (2018). The effect of compulsory service on life satisfaction and its channels. IAB Discussion Paper, 24/2018.

Deter, M. (2020). Prosociality and risk preferences in the financial sector. SOEPpapers on Multidisciplinary Panel Data Research No. 1075.

Diener, E., Lucas, R. E., \& Scollon, C. N. (2006). Beyond the hedonic treadmill: Revising the adaptation theory of well-being. American Psychologist, 61(4), 305-314.

Die Zeit. (2004). Wie aus mehr weniger wird. Die Bundesregierung benutzt Hartz IV, um klammheimlich die Sozialhilfe zu senken. https://www.zeit.de/2004/52/ALG_II. Accessed 3 March 2020.

Die Zeit. (2018). Wie fies ist Hartz IV? https://www.zeit.de/2018/49/hartz-iv-grundsicherung-sanktionen -existenzminimum-sozialleistungen. Accessed 3 March 2020. 
Dohmen, T., Falk, A., Huffman, D., \& Sunde, U. (2012). The intergenerational transmission of risk and trust attitudes. The Review of Economic Studies, 79(2), 645-677.

Dolan, P., Peasgood, T., \& White, M. (2008). Do we really know what makes us happy? A review of the economic literature on the factors associated with subjective well-being. Journal of Economic Psychology, 29(1), 94-122.

Eggs, J. (2013). Unemployment benefit II, unemployment and health. IAB Discussion Paper, 12/2013.

Eichhorst, W., \& Marx, P. (2011). Reforming German labour market institutions: A dual path to flexibility. Journal of European Social Policy, 21(1), 73-87.

Eurostat. (2020). Unemployment rate-Seasonally adjusted data. https://appsso.eurostat.ec.europa.eu/nui/ show.do?dataset=une_rt_m\&lang=en. Accessed 3 March 2020.

Federal Statistical Office of Germany. (2020). Registered unemployed, unemployment as a percentage of the civilian labour force, registered vacancies: Länder, years. https:/www-genesis.destatis.de/genesis/ online?operation=sprachwechsel\&language=en. Accessed 3 March 2020.

Ferrer-i-Carbonell, A. (2005). Income and well-being: An empirical analysis of the comparison income effect. Journal of Public Economics, 89(5-6), 997-1019.

Ferrer-i-Carbonell, A., \& Frijters, P. (2004). How important is methodology for the estimates of the determinants of happiness? The Economic Journal, 114(497), 641-659.

Frey, B. S., \& Stutzer, A. (2002). What can economists learn from happiness research? Journal of Economic Literature, 40(2), 402-435.

Gardner, J., \& Oswald, A. J. (2007). Money and mental wellbeing: A longitudinal study of medium-sized lottery wins. Journal of Health Economics, 26(1), 49-60.

Gielen, A. C., \& Van Ours, J. C. (2014). Unhappiness and job finding. Economica, 81(323), 544-565.

Goebel, J., Grabka, M., Liebig, S., Kroh, M., Richter, D., Schröder, C., et al. (2019). The German SocioEconomic Panel Study (SOEP). Jahrbücher für Nationalökonomie und Statistik/Journal of Economics and Statistics, 239(2), 345-360.

Goebel, J., \& Richter, M. (2007). Nach der Einführung von Arbeitslosengeld II: Deutlich mehr Verlierer als Gewinner unter den Hilfeempfängern. DIW Wochenbericht, 74(50), 753-761.

Grant, A. M., \& Schwartz, B. (2011). Too much of a good thing: The challenge and opportunity of the inverted U. Perspectives on Psychological Science, 6(1), 61-76.

Gruber, J., \& Mullainathan, S. (2005). Do cigarette taxes make smokers happier? The B.E. Journal of Economic Analysis and Policy, 5(1), 1-45.

Headey, B., Kelley, J., \& Wearing, A. (1993). Dimensions of mental health: Life satisfaction, positive affect, anxiety and depression. Social Indicators Research, 29(1), 63-82.

Hertweck, M. S., \& Sigrist, O. (2012). The aggregate effects of the Hartz reforms in Germany. Working Paper University of Konstanz, 83/2012.

Hochmuth, B., Kohlbrecher, B., Merkl, C., \& Gartner, H. (2019). Hartz IV and the decline of German unemployment: A macroeconomic evaluation. IZA Discussion Paper, 12260.

Kahneman, D. (2006). Objective happiness. Well-Being: The Foundations of Hedonic Psychology, 3(25), $1-23$.

Kettner, A., \& Rebien, M. (2007). Hartz-IV-Reform: Impulse für den Arbeitsmarkt. IAB Kurzbericht, $19 / 2007$.

Kosse, F., Deckers, T., Pinger, P., Schildberg-Hörisch, H., \& Falk, A. (2020). The formation of prosociality: Causal evidence on the role of social environment. Journal of Political Economy, 128(2), 434-467.

Krause, M. U., \& Uhlig, H. (2012). Transitions in the German labor market: Structure and crisis. Journal of Monetary Economics, 59(1), 64-79.

Layard, R. (2011). Happiness: Lessons from a new science. London: Penguin.

Lucas, R. E., Clark, A. E., Georgellis, Y., \& Diener, E. (2004). Unemployment alters the set point for life satisfaction. Psychological Science, 15(1), 8-13.

Manager Magazin. (2001). Es gibt kein Recht auf Faulheit. http://www.manager-magazin.de/unternehmen/ artikel/a-126811.html. Accessed 3 March 2020.

Oswald, A. J. (1997). Happiness and economic performance. The Economic Journal, 107(445), 1815-1831.

Schwarz, N., \& Strack, F. (1999). Reports of subjective well-being: Judgmental processes and their methodological implications. Well-Being: The Foundations of Hedonic Psychology, 7, 61-84.

Statista. (2019). Anteil der Langzeitarbeitslosen an allen Arbeitslosen in Deutschland von 1993 bis 2019. https://de.statista.com/statistik/daten/studie/17425/umfrage/anteil-der-langzeitarbeitslosen-in-deuts chland/. Accessed 3 March 2020.

Statista. (2020). Höhe des Hartz IV Regelsatzes von 2005 bis 2019. https://de.statista.com/statistik/daten/ studie/241114/umfrage/entwicklung-des-hartz-iv-regelsatzes/. Accessed 3 March 2020.

Süddeutsche Zeitung. (2019). Wie die Parteien Hartz IV reformieren wollen. www.sueddeutsche.de/wirts chaft/hartz-iv-reform-gruene-spd-fdp-1.4339922. Accessed 3 March 2020. 
The Economist. (2018). What the German economic model can teach Emmanuel Macron. https://www. economist.com/finance-and-economics/2017/05/27/what-the-german-economic-model-can-teach -emmanuel-macron. Accessed 3 March 2020.

Thomsen, S. L., Walter, T., \& Boockmann, B. (2009). Intensifying the use of benefit sanctions-An effective tool to shorten welfare receipt and speed up transitions employment? ZEW-Centre for European Economic Research Discussion Paper, 09-072.

Veenhoven, R. (2008). Healthy happiness: Effects of happiness on physical health and the consequences for preventive health care. Journal of Happiness Studies, 9(3), 449-469.

Warr, P. (1987). Work, unemployment, and mental health. Oxford: Oxford University Press.

Wirtschaftsdienst. (2019). Hartz IV-Reform einer umstrittenen politischen Maßnahme. Wirtschaftsdienst, $4,235-255$.

Woodcock, S. D. (2018). The effect of the Hartz labor market reforms on post-unemployment outcomes, sorting, and matching. IZA Conference Paper, 2018.

Zick, A., Küpper, B., \& Berghan, W. (2019). Verlorene Mitte-Feindselige Zustände: Rechtsextreme Einstellungen in Deutschland 2018/19. https://www.fes.de/forum-berlin/gegen-rechtsextremismus/mitte -studie/. Accessed 3 March 2020.

Publisher's Note Springer Nature remains neutral with regard to jurisdictional claims in published maps and institutional affiliations. 